\title{
無症候性縦隔気腫の後に両側気胸を 発症した多発性筋炎の一例
}

田中 宏和, 川辺 正和, 渡辺 裕介, 中出 雅治

\begin{abstract}
要 旨
症例はシェグレン症候群を合併する多発性筋炎（Polymyositis，以下 PM）と診断された56歳の男性．無症候性縦隔 気腫出現後に両側気胸を発症したため持続胸腔ドレナージを開始した。約 1 カ月間，気漏が持続したため，胸腔鏡を 用いて一期的に両側気漏箇所を切除し気胸は改善した。多発性筋炎における無症候性縦隔気腫の報告は稀であり, 自 験例は多発筋炎が合併した気胸に対する 2 例目の手術報告である.
\end{abstract}

索引用語：多発性筋炎，無症候性縦隔気腫，両側気胸，胸腔鏡手術 polymyositis, asymptomatic pneumomediastinum, bilateral pneumothorax video-assisted thoracoscopic surgery

\section{はじめに}

膠原病のなかで無症候性縦隔気腫の報告は皮膚筋炎 （Dermatomyositis，以下 DM）に多く, 類縁疾患の多 発性筋炎 (Polymyositis, 以下 PM) では殆ど報告され ていない，また，われわれが検索した限りでは，自験 例は多発性筋炎が合併した気胸に対する 2 例目の手術 報告であるため文献的考察を加えて報告する。

\section{症例}

症 例：56歳, 男性.

主 訴: 脱力感.

現病歴：労作時呼吸困難, 筋力低下を自覚するよう になり誤嬹・嗄声が出現したため近医受診. 胸部レン トゲン写真で異常影を指摘されたため, 2 カ月後精 査・加療目的にて当院呼吸器内科に紹介入院となる.

既往歴：42歳時胃潰瘍，47歳〜うつ病.

家族歴：母, 腎細胞癌.

喫煙歴：20４2歳，一日20本.

大阪赤十字病院 呼吸器外科

原稿受付 2007 年 5 月21日

原稿採択 2007 年 7 月 30 日
入院時現症：身長 $173.5 \mathrm{~cm}$, 体重 $53 \mathrm{~kg}, \mathrm{BT} 36.7^{\circ} \mathrm{C}$, BP110/70mmHg, HR92/min, 整. 両下肺野で Velcro ラ音を聴取。四肢近位筋の筋力低下，眼・ 口腔粘膜の 乾燥を認めた。ヘリオトロープ疹, Gottron 徵候を認 めず.

入院時検査データでは白血球数増多, GOT, GPT, ALP, LDH, CPK, CPK-MB, myoglobin, CRP, BS, KL $6,1 \rightarrow 3 \beta$-D glucan 值の上昇を認め, 抗核抗体, 抗 SS-A 抗体, 抗 SS-B 抗体, 抗 DNA 抗体, RAPA が 陽性であった。呼吸機能検查では拘束性肺障害, 肺拡 散能低下, 低酸素血症を認めた (Table 1$)$ 。入院時胸部 $\mathrm{XP} \cdot \mathrm{CT}$ では両肺の間質影増強と下肺野の蜂窩様変化, 両肺の囊胞性変化を認めた。 上腕二頭筋の生検では太 さが不均一な筋繊維と筋纎維の壊死と再生像，血管周 囲へのリンパ球浸潤を認めた（Fig. 1A）。さらに口唇 生検でリンパ球, 形質細胞浸潤, 口唇腺萎縮, 繊維化 を認めたことから，シェグレン症候群を合併する PM と診断した。

入院後経過：入院後 2 週間後にステロイド治療が開 始されてから筋力低下，血中筋原性酵素の值は改善し たが，ステロイド開始から約 2 週間後に重度のうつ状 態に陥ったため，ステロイド投与量の減量を開始した 
Table 1 Laboratory findings on admission

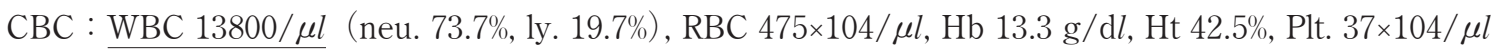

Biochemistry : TP $8.3 \mathrm{mg} / \mathrm{d} l$, alb $3.2 \mathrm{mg} / \mathrm{d} l$, GOT $159 \mathrm{IU} / l$, GPT $131 \mathrm{IU} / l$, ALP $555 \mathrm{IU} / l$, LDH $602 \mathrm{IU} / l$, CPK $3126 \mathrm{IU} / l$, CPK-MB $212 \mathrm{IU} / l$, myoglobin $2467 \mathrm{ng} / \mathrm{ml}$, CRP $2.0 \mathrm{mg} / \mathrm{d} l$, BS $141 \mathrm{mg} / \mathrm{d} l, \mathrm{Na} 141 \mathrm{mEq} / 1, \mathrm{~K} 4.4 \mathrm{mEq} / \mathrm{l}$, Cl $105 \mathrm{mEq} / \mathrm{l}$, Ca $4.4 \mathrm{mEq} / \mathrm{l}, \mathrm{BUN} 12.5 \mathrm{mg} / \mathrm{d} l$, Cre $0.5 \mathrm{mg} / \mathrm{d} l$, KL6 $1140 \mathrm{U} / \mathrm{ml}$, SP-D $116 \mathrm{ng} / \mathrm{ml}$, CEA $0.7 \mathrm{ng} / \mathrm{ml}$, CA 19-9 $3.4 \mathrm{U} / \mathrm{ml}$, AFP $4.0 \mathrm{ng} / \mathrm{ml}$, F-T3 $2.71 \mathrm{pg} / \mathrm{ml}$, TSH $1.92 \mathrm{IU} / \mathrm{ml}, \underline{1 \rightarrow 3 \beta}-\mathrm{D}$ glucan $22.6 \mathrm{pg} / \mathrm{ml}$

Serology : ANA 40x, anti-Jo1 $(-)$, anti-Scl70 $(-)$, anti-SSA $(+)$, anti-SSB $(+)$, anti-DNA $(+)$, P-ANCA $(-), C^{-}$ $\operatorname{ANCA}(-), \overline{R F}<20, \operatorname{RAPA} 80(<40)$, Aspergillus $\operatorname{Ag}(-)$

Pulmonary function test : VC $2200 \mathrm{ml}$, \%V 59.1\%, FEV $1.02250 \mathrm{ml}$, FEV 1.0\% 99.1\%, \%DLCO 61.5\%

Arterial blood gas analysis (RA) : $\mathrm{PaCO}_{2} 48.6$ Torr, $\mathrm{PaO}_{2} 78.3$ Torr, $\mathrm{HCO}_{3} 29.3 \mathrm{mmol} / \mathrm{l}$, BE $5.5 \mathrm{mmol} / 1$

Laboratory data on admission indicated leukocytosis and elevation of GOT, GPT, ALP, LDH, CPK, CPK-MB, myoglobin, CRP, KL6, and $1 \rightarrow 3 \beta-$ D glucan. Serological examination showed that ANA, anti-SSA, ant-SSB and RAPA were positive. These data were compatible with myositis, interstitial pneumonia, and fungal infection. A pulmonary function test revealed restrictive dysfunction.

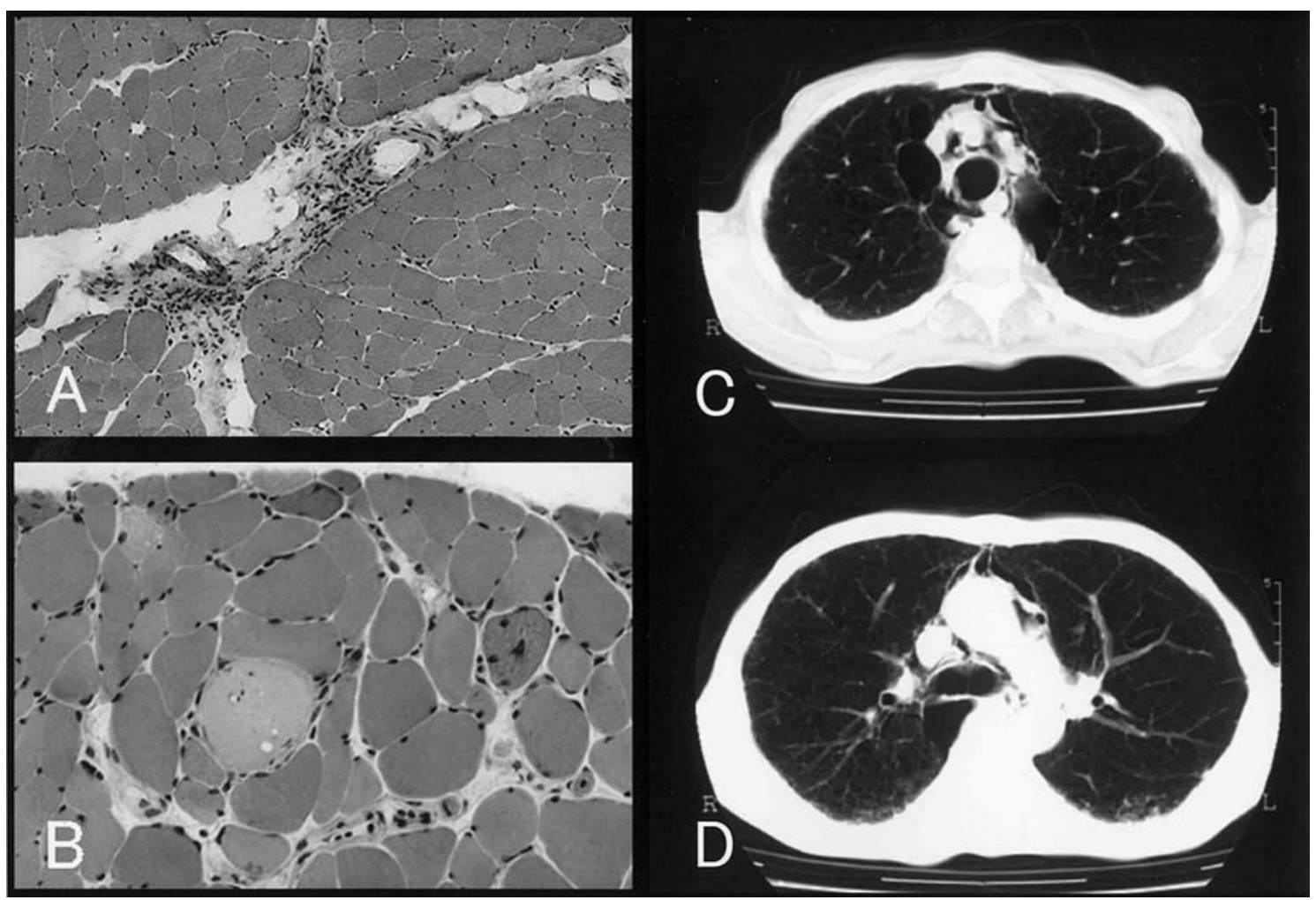

Fig. 1 A, B: Histology of the biceps brachii muscle revealed that muscular fibers didn't show uniformity in size due to necrosis and regeneration of the fibers with perivascular infiltration of lymphocytes (H. E. stain). C, D: Chest CTs at the onset of the pneumomediastinum show that an air space exists between mediastinal structures, and cystic lesions are recognized in the bilateral lungs.

減量開始して間もなく縦隔気腫の出現を認め，右，左 の順に気胸を発症したため両側胸腔ドレナージが開始 された (Table 2). ドレナージ開始から約 1 カ月経過 しても気漏は消失せず，患者が両側の胸腔ドレーンの
抜去を強く希望したため当科で両側気胸に対して胸腔 鏡による一期的手術を行った。

術中所見: 両側肺先部には $5 \sim 10 \mathrm{~cm}$ 大の壁の肥厚し たブレブ様病変を多数認め, それらの表面は厚いフィ 
Table 2 Clinical course

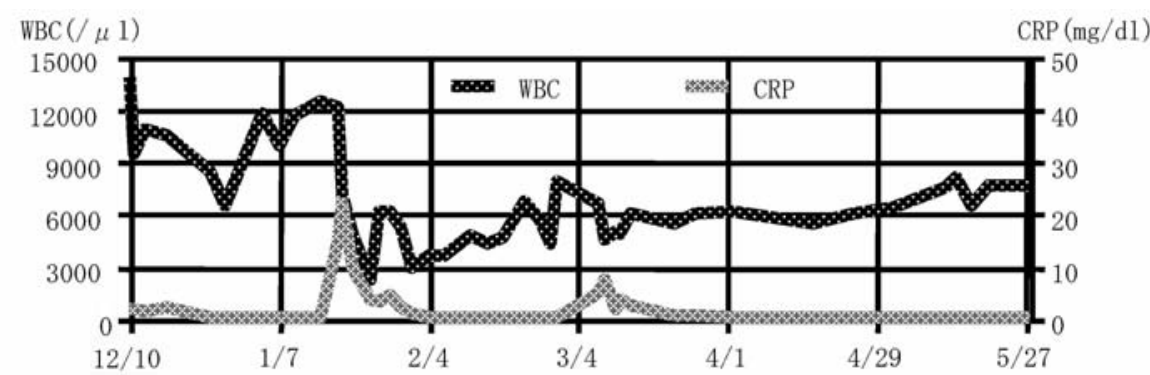

CPK, $\mathrm{CK}-\mathrm{MB}(\mathrm{IU} / 1)$

Myoglobin (ng/ml)

$\mathrm{CK}-\mathrm{MB} / \mathrm{CK}(\%)$

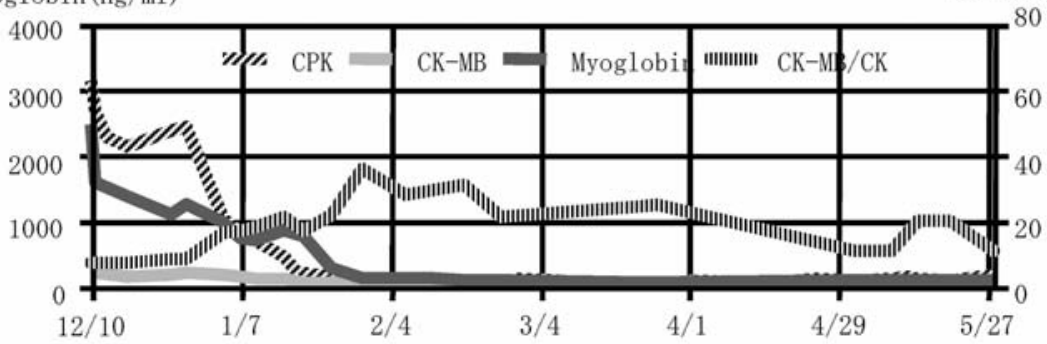

$\mathrm{LDH}(\mathrm{IU} / 1)$

$\mathrm{KL}-6(\mathrm{U} / \mathrm{ml})$

$\beta-D$ glucan $(\mathrm{pg} / \mathrm{ml})$
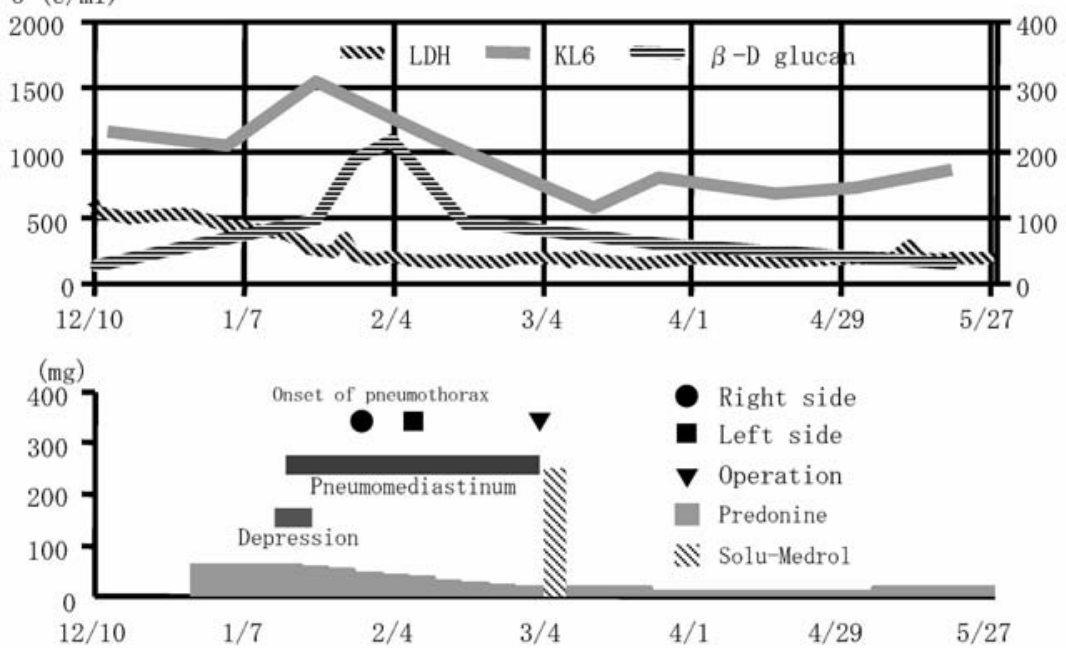

Administration of predonine was started for the treatment of PM, and laboratory data (WBC, CK, CK-MB, LDH, and KL6) were improved. After a while, gradual reduction of the steroid dose was started, because he became depressed. Then, pneumomediastinum appeared, followed by bilateral pneumothorax.

ブリン膜で覆われていた（Fig. 2A)。 大きさ約 $2 \mathrm{~mm}$ の気漏孔を有する両側のブレブを Polyglycolic acid (PGA) フェルトチューブタイプ（NEOVEIL, GUNZE）を併用して staplingにより切除した。 これに より気漏は消失し, 術後 3 日目には両側ドレーンを抜 去できた。切除肺の病理検査では，大小不同の囊胞が 多数形成されており, 間質の線維化と炎症細胞浸潤を 認めた（Fig. 2B）。術後，間質性肺炎は増悪すること
なく順調に経過， 3 月末に摂食機能訓練を開始し 5 月 末に退院となった。

\section{考察}

縦隔気腫は咳, 嘔吐, 排便時の急激な肺胞内圧上昇 によって肺胞が破裂する特発性, 気道・食道損傷によ る外傷性，肺炎，細気管支炎，間質性肺炎などによる 続発性に分けられる ${ }^{1,2)}$. 続発性のうち膠原病の縦隔 


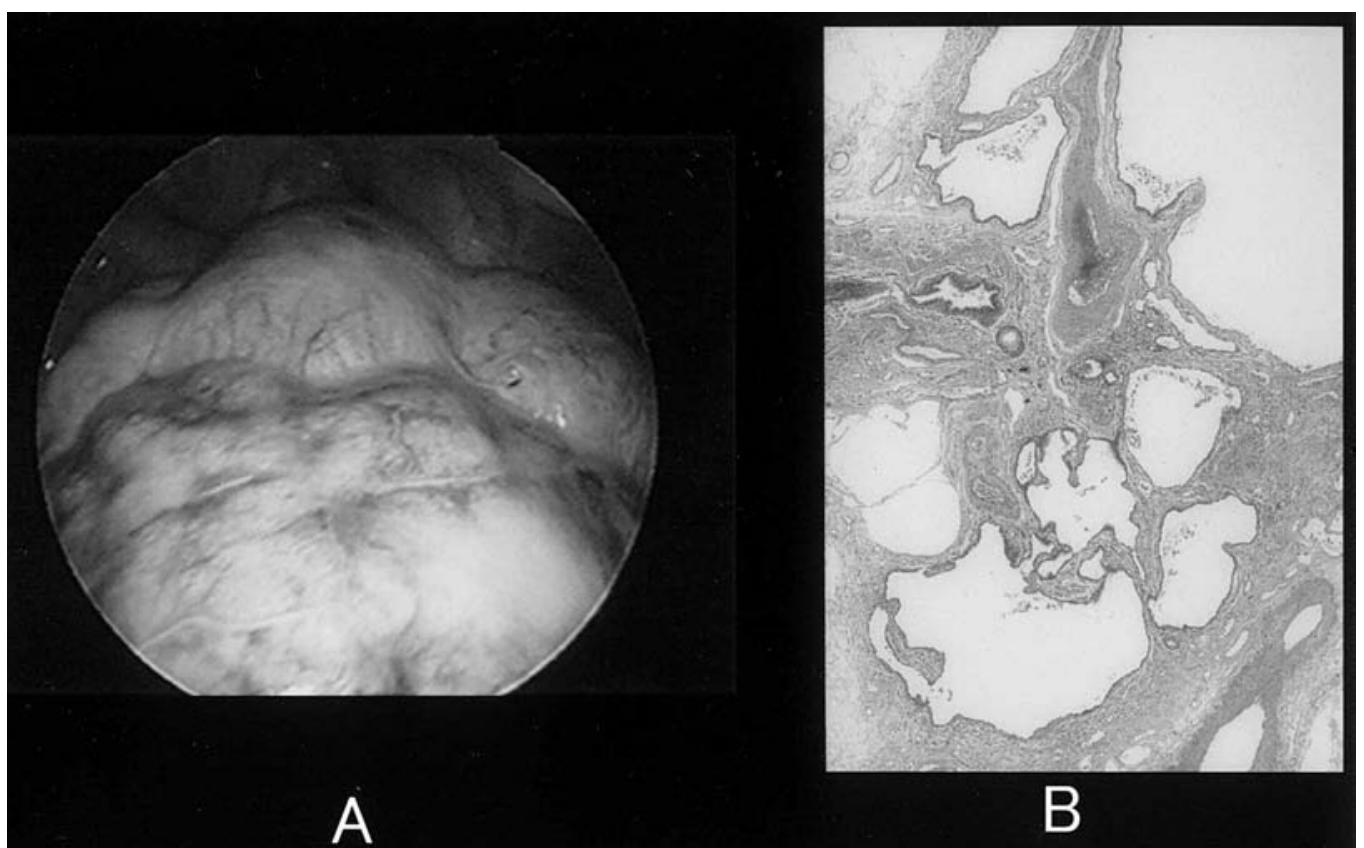

Fig. 2 A: Photograph during the operation indicates that a thick pleura coated with fibrin appeared to be whitish, with multiple bleb-like lesions. B: Histology of the bleb-like lesions indicates formation of multiple cysts and air spaces, and interstitial fibrosis and thickness.

気腫は DM に多く報告されているため, 縦隔気腫は DM に特徵的な合併症と考えられている2-6). DM が 合併した縦隔気腫は難治性で, 殆どが間質性肺炎の増 悪に伴って出現し半数以上が呼吸不全で死亡している ことから縦隔気腫は予後不良の徵候とされる ${ }^{2-6)}$.こ の縦隔気腫の発生機序は不明で, 肺血管周囲組織に隣 接する肺胞が胸腔内圧上昇によって破裂し, 漏出した 空気が肺血管に沿って肺門から縦隔へと移動すること によると考えられている2,4-6). DM に縦隔気腫が多い 理由として, 血管炎による微小梗塞・壊死あるいは誤 舆性肺炎による血管周囲組織の脆弱化が考えられてお り, 類縁疾患のPM でも同様の機序で縦隔気腫が起こ るものと考えられる2,4-6). また筋炎症状の改善や間 質性肺炎治療にステロイド剤が用いられていることか ら，ステロイド剤による組織の修復能低下と脆弱化が DM の縦隔気腫発症に関与しているとの意見もあ $3^{2,4-6)}$. しかし他の膠原病治療にもステロイド剤が 使われていることや，ステロイド剂投与により縦隔気 腫が改善したとの報告もあるため, ステロイド剤の使 用が縦隔気腫を起こす主な原因であるとは考えにく $(2,4)$.

PM の気胸手術例を最初に報告したSatoらは, 手術
中にブレブ様病変を多数認めたことから PM の中には 肺線維症を合併しなくても胸膜病変を生じるものがあ ると述べている7). 自験例は肺線維症を合併していた が, Satoらと同じような多発性ブレブ様病変を認め, 切除肺病理検查でも多数の気腔や囊胞形成を認めた. 膠原病の気胸の原因は肺線維化によって形成された囊 胞とされているが, PM では肺線維症の有無にかかわ らず囊胞を形成する胸膜変化が起こり易いのかも知れ ない，膠原病が合併する気胸は間質性肺炎の増悪時に 見られることが多いため, 殆どが手術対象にはならな い. また気腫性変化が強い肺では, 切離に用いた自動 縫合器の針穴や縫合線からの気漏が持続することがあ り, 気漏を予防するために自動縫合器使用時に PGA フェルトが併用されている8). 自験例でも PGAフェル 卜を併用することで, 術直後から気漏は消失し, 再側 胸腔ドレーンの早期抜去が可能となった。 今回われわ れが報告した多発筋炎症例は難治性両側気胸に対して 胸腔鏡による一期的手術を行い, 良好な結果を得た貴 重な症例と考えられる。

\section{謝辞}

本症例の病理組織検査を行っていただきました本院 
病理部，新宅雅幸先生に深く感謝いたします。

\section{文献}

1. 正岡 昭, 藤井義敬, 山川洋右, 他. 縦隔気腫. 藤井義 敬編集. 呼吸器外科学. 改訂 3 版. 東京: 南山堂; 2003: 291-5.

2. 里美和彦, 道端達也, 飯塚文朗, 福田博司, 宮下哲一, 皮 膚筋炎関連肺線維症の経過中に縱隔気腫を繰り返した 1 例. 日呼吸会誌 1998; 36: 984-8.

3. 津田恭彦, 野口雅章, 小林茂人, 橋本博史, 廣瀨俊一, 慢 性関節リウマチと多発性筋炎の重複例に, 間質性肺炎, 気胸, 縦隔気腫を合併した 1 剖検例。関東リウマチ 1993; 27: 643-7.

4. Hiroshi Maruoka, Seiyo Honda, Masaaki Takeo, et al. A case of plymmyositis complicated with interstitial pneu- monitis and pneumomediastinum. Modern Rheumotol 2006; 16: 55-7.

5. 浜本康夫，高橋裕樹，松永隆弘，他，無症候性縦隔気腫 の合併を認めた皮膚筋炎の 1 例。日臨免疫会誌 1998; 21: $213-9$.

6. 中村 正, 山村雄治, 鶴田敬郎, 松原三郎, 友田邦彦, 束野通司。縦隔気腫などの多彩な臨床症状を伴う皮膚筋 炎の一例。九州リウマチ 2000; 19: 88-92.

7. Sato M, Bando T, Hasegawa S, et al. Recurrent spontaneous pneumothoraces associated with juvenile polymyositis. CHEST 2000; 118: 1509-11.

8. 吉谷克雄, 富樫賢一, 佐藤良智. 自動縫合器と PGA フェ ルトによる胸腔鏡下高齢者気胸手術の 1 例。胸部外科 1995; 48: 833-5.

\title{
A case of polymyositis complicating asymptomatic pneumomediastinum followed by bilateral pneumothorax
}

\author{
Hirokazu Tanaka, Masakazu Kawabe, Masaharu Nakade, Hiroyoshi Watanabe \\ Department of Chest Surgery, Osaka Red Cross Hospital, Japan
}

A 56-year-old Japanese male, given a diagnosis of polymyositis (PM) with Sjögren's syndrome, was admitted to our hospital. Bilateral pneumothorax occurred after asymptomatic pneumomediastinum. Therefore, bilateral tube drainage was started and air leakage continued for about a month. Video-assisted thoracoscopic surgery for bilateral pneumothorax was performed, and the air leakage disappeared. To our knowledge, this report is not only the second case of polymiositis that was received surgery of pneumothorax, but also the second case of polymiositis complicating asymptomatic pneumomedastinum. 